Article

\title{
Hydrogen Sulfide Attenuates Hydrogen Peroxide-Induced Injury in Human Lung Epithelial A549 Cells
}

\author{
Mingqi Wang, Xinyu Cao, Chang Luan and Zhengqiang Li * \\ Key Laboratory for Molecular Enzymology and Engineering of Ministry of Education, College of Life Sciences, \\ Jilin University, Changchun 130012, China \\ * Correspondence: lzq@jlu.edu.cn; Tel.: +86-0431-85155200
}

Received: 2 July 2019; Accepted: 14 August 2019; Published: 15 August 2019

check for updates

\begin{abstract}
Lung tissues are frequently exposed to a hyperoxia environment, which leads to oxidative stress injuries. Hydrogen sulfide $\left(\mathrm{H}_{2} \mathrm{~S}\right)$ is widely implicated in physiological and pathological processes and its antioxidant effect has attracted much attention. Therefore, in this study, we used hydrogen peroxide $\left(\mathrm{H}_{2} \mathrm{O}_{2}\right)$ as an oxidative damage model to investigate the protective mechanism of $\mathrm{H}_{2} \mathrm{~S}$ in lung injury. Cell death induced by $\mathrm{H}_{2} \mathrm{O}_{2}$ treatment could be significantly attenuated by the pre-treatment of $\mathrm{H}_{2} \mathrm{~S}$, resulting in a decrease in the Bax/Bcl-2 ratio and the inhibition of caspase- 3 activity in human lung epithelial cell line A549 cells. Additionally, the results showed that $\mathrm{H}_{2} \mathrm{~S}$ decreased reactive oxygen species (ROS), as well as neutralized the damaging effects of $\mathrm{H}_{2} \mathrm{O}_{2}$ in mitochondria energy-producing and cell metabolism. Pre-treatment of $\mathrm{H}_{2} \mathrm{~S}$ also decreased $\mathrm{H}_{2} \mathrm{O}_{2}$-induced suppression of endogenous $\mathrm{H}_{2} \mathrm{~S}$ production enzymes, cystathionine-beta-synthase (CBS), cystathionine-gamma-lyase (CSE), and 3-mercapto-pyruvate sulfurtransferase (MPST). Furthermore, the administration of $\mathrm{H}_{2} \mathrm{~S}$ attenuated $\left[\mathrm{Ca}^{2+}\right]$ overload and endoplasmic reticulum (ER) stress through the mitogen-activated protein kinase (MAPK) signaling pathway. Therefore, $\mathrm{H}_{2} \mathrm{~S}$ might be a potential therapeutic agent for reducing ROS and ER stress-associated apoptosis against $\mathrm{H}_{2} \mathrm{O}_{2}$-induced lung injury.
\end{abstract}

Keywords: Hydrogen sulfide; hydrogen peroxide; reactive oxygen species; endoplasmic reticulum stress; lung injury

\section{Introduction}

Hydrogen sulfide $\left(\mathrm{H}_{2} \mathrm{~S}\right)$ is a poisonous, flammable gas, with the smell of rotten eggs, and is simply regarded as an environmental pollutant [1]. Recently, $\mathrm{H}_{2} \mathrm{~S}$ has been considered the third signaling gasotransmitter, accompanying nitric oxide and carbon monoxide, due to its multiple functions in physiological and pathological processes [2,3]. Studies have shown that $\mathrm{H}_{2} \mathrm{~S}$ participates in cardiovascular remodeling, cell proliferation, migration and invasion, oxidative stress, and inflammation [4-6]. Endogenous $\mathrm{H}_{2} \mathrm{~S}$ is mainly produced from L-cysteine via reactions catalyzed by three enzymes: cystathionine-beta-synthase (CBS), cystathionine-gamma-lyase (CSE), and 3-mercapto-pyruvate sulfurtransferase (MPST) [7,8]. Recent reports have shown that a multitude of $\mathrm{H}_{2} \mathrm{~S}$-releasing small-molecule drugs, such as $\mathrm{H}_{2} \mathrm{~S}$-hybrid nonsteroidal anti-inflammatory drugs (HS-NSAIDS), showed a significant reduction of gastrointestinal damage compared to the parent NSAIDS $[9,10]$.

The lung is the most important respiratory organ involved in gas exchange that is frequently in contact with the ambient air, including nitrogen dioxide, sulfur dioxide, ozone, cigarette smoke, and diesel exhaust [11,12]. Exposure to a hyperoxia environment increases the intracellular production of reactive oxygen species (ROS) [13]. Meanwhile, a large amount of superoxide anions caused by viral 
infection, drugs, or surgery also results in oxidative stress injuries [14-16]. ROS induces structural and functional abnormalities in the mitochondrial electron transport chain, and the imbalance between antioxidants and oxidants can cause cell injury and even death $[17,18]$. Therefore, ROS is the basis of many lung diseases.

The endoplasmic reticulum (ER) is an organelle responsible for the synthesis, folding, assembly, and modification of proteins [19]. In pathological conditions, ER dysfunction and calcium dyshomeostasis lead to an excessive accumulation of unfolded or misfolded proteins, which induces ER stress [20]. A growing number of studies have suggested that ER stress plays critical roles in many physiological and pathological processes, including allergy and inflammation, Alzheimer's disease, cardiovascular disease, and obesity [21-24]. ER stress is also a common cause of lung diseases, indicating that a misfolded protein may be an important unifying mechanism in pulmonary fibrosis and even lung cancer [25].

Our previous study found that sodium hydrosulfide (NaHS), as the exogenous $\mathrm{H}_{2} \mathrm{~S}$ donor, regulated the cell proliferation and angiogenesis of A549 cells. Despite its function in tumor growth, the effects of $\mathrm{H}_{2} \mathrm{~S}$ on ER stress in the human lung epithelial cell line A549 remain to be elucidated. In the present study, hydrogen peroxide $\left(\mathrm{H}_{2} \mathrm{O}_{2}\right)$ was chosen as the model of lung injury in vitro. We investigated whether $\mathrm{H}_{2} \mathrm{~S}$ protected $\mathrm{A} 549$ cells against oxidation-induced ER stress. In this paper, we present evidence that ER stress contributed to $\mathrm{H}_{2} \mathrm{O}_{2}$-induced apoptosis in human lung epithelial cells via the MAPK signaling pathway. Our research provides a novel treatment of oxidative-related diseases with $\mathrm{H}_{2} \mathrm{~S}$.

\section{Results}

\subsection{Protective Effect of $\mathrm{H}_{2} \mathrm{~S}$ on Human Lung Epithelial Cells against $\mathrm{H}_{2} \mathrm{O}_{2}$-Induced Apoptosis}

As shown in Figure 1A, different concentrations of NaHS were added to the culture medium of human lung epithelial cells for $12 \mathrm{~h}$. Cell activities increased most obviously in $50 \mu \mathrm{M}$ NaHS treatment. A549 cells were then incubated with different concentrations of $\mathrm{H}_{2} \mathrm{O}_{2}$ for $12 \mathrm{~h}$, and the half maximal inhibitory concentration $\left(\mathrm{IC}_{50}\right.$ ) was $60.25 \mathrm{mM}$ (Figure 1B). Therefore, the concentration of $60 \mathrm{mM}$ was chosen for the model of $\mathrm{H}_{2} \mathrm{O}_{2}$-induced lung injury. The cell state in the $\mathrm{H}_{2} \mathrm{~S}+\mathrm{H}_{2} \mathrm{O}_{2}$ group was better than that in the $\mathrm{H}_{2} \mathrm{O}_{2}$ group under an optical microscope (Figure 1E). To further determine whether $\mathrm{H}_{2} \mathrm{~S}$ had a protective effect on $\mathrm{H}_{2} \mathrm{O}_{2}$-induced apoptosis, A549 cells were pre-treated with $\mathrm{H}_{2} \mathrm{~S}$ for $2 \mathrm{~h}$ and then subjected to $\mathrm{H}_{2} \mathrm{O}_{2}$. As shown in Figure $1 \mathrm{C}, \mathrm{H}_{2} \mathrm{~S}$ obviously reduced $\mathrm{H}_{2} \mathrm{O}_{2}$ cytotoxicity. The flow cytometric analysis confirmed that the cell apoptosis rate in the $\mathrm{H}_{2} \mathrm{~S}$ pre-treatment group was significantly decreased compared with that in the $\mathrm{H}_{2} \mathrm{O}_{2}$ group (Figure 1D). A colony formation assay indicated that the A549 cells in the $\mathrm{H}_{2} \mathrm{O}_{2}$ group were barely forming clones. With pre-treatment of $\mathrm{H}_{2} \mathrm{~S}$, A549 cells could form a few clones (Figure 1E). The expression of apoptosis genes was further examined. Compared to the untreated cells, A549 cells expressed more cleaved-caspase 3 when treated with $\mathrm{H}_{2} \mathrm{O}_{2}$. Meanwhile, the activity of caspase 3 was decreased in the protection group compared with the injury group (Figure $1 \mathrm{~F}$ ). The ratio of $\mathrm{Bax}$ and $\mathrm{Bcl}-2$ mRNA expression was markedly decreased when pre-treated with $\mathrm{H}_{2} \mathrm{~S}$ compared to that in the $\mathrm{H}_{2} \mathrm{O}_{2}$ group. Western blot analysis was in agreement with the quantitative real-time PCR (qRT-PCR) results, showing that the protein expression of Bax was up-regulated and Bcl-2 was down-regulated in the $\mathrm{H}_{2} \mathrm{O}_{2}$ group. $\mathrm{H}_{2} \mathrm{~S}$ pre-treatment could decrease Bax expression and increase Bcl-2 expression (Figure 1G). These results indicated that $\mathrm{H}_{2} \mathrm{~S}$ reduced $\mathrm{H}_{2} \mathrm{O}_{2}$-induced injury in lung epithelial cells. 
A

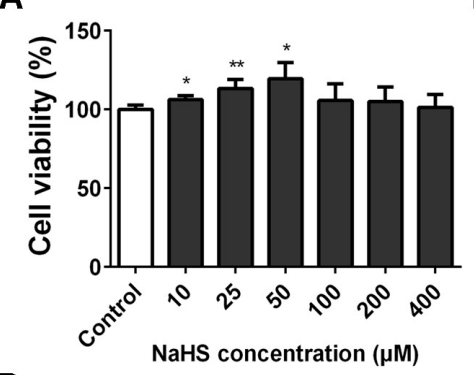

D

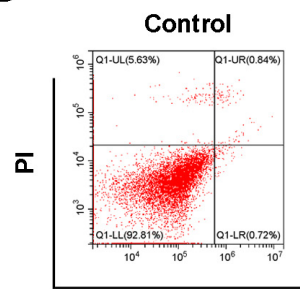

B

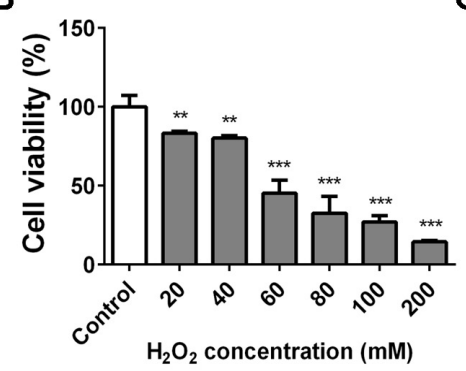

C

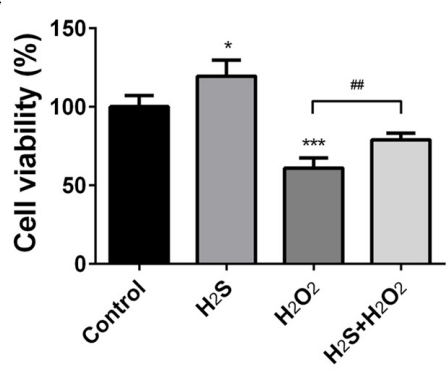

E

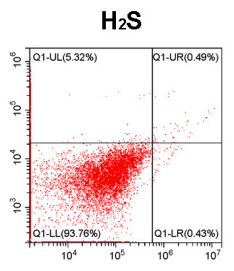

$\mathrm{H}_{2} \mathrm{O}_{2}$

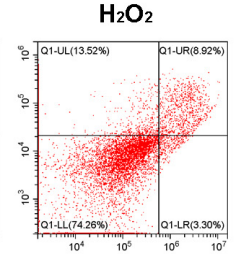

$\mathrm{H}_{2} \mathrm{~S}+\mathrm{H}_{2} \mathrm{O}_{2}$

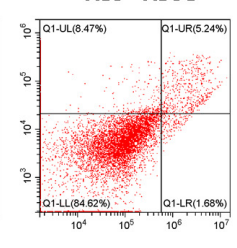

Annexin V
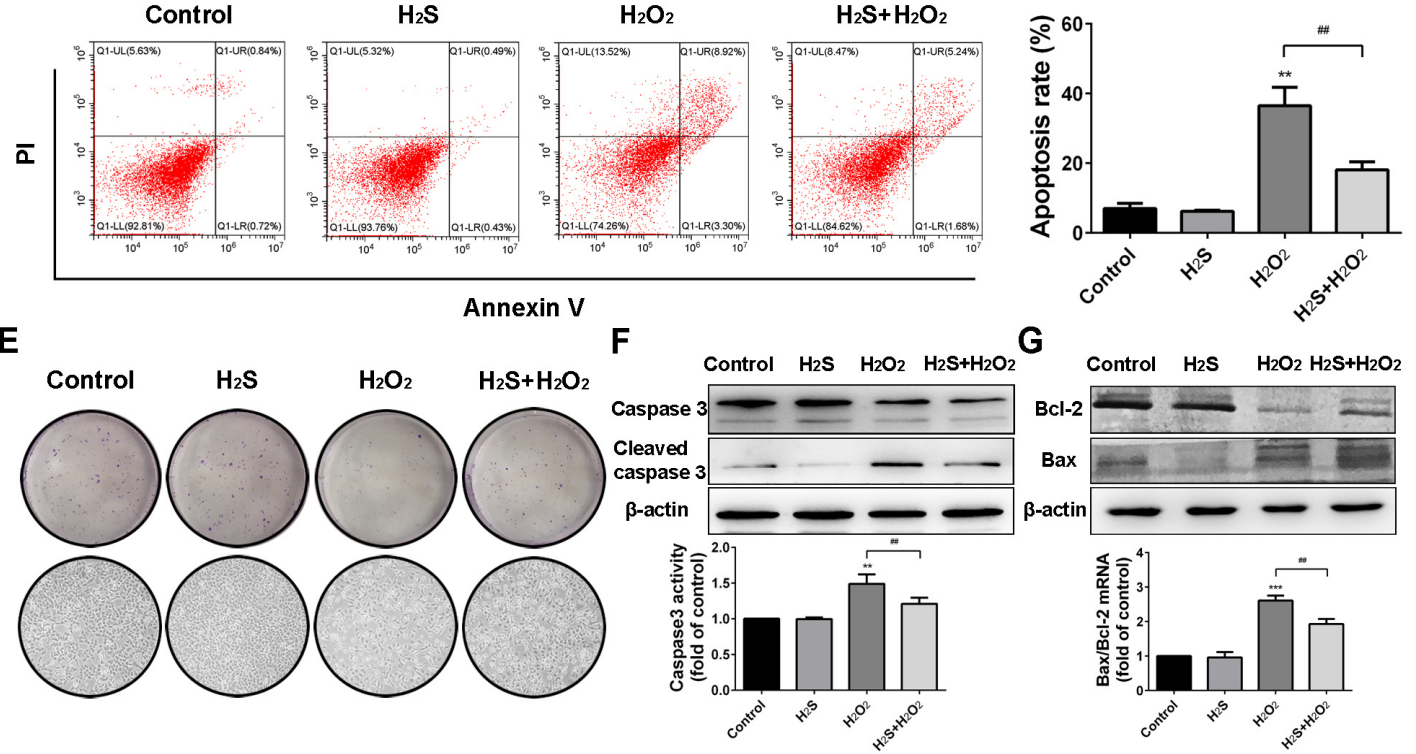

Figure 1. Hydrogen sulfide $\left(\mathrm{H}_{2} \mathrm{~S}\right)$ reduced hydrogen peroxide $\left(\mathrm{H}_{2} \mathrm{O}_{2}\right)$-induced injury in A549 cells. (A) Cell viability assay. After incubation with sodium hydrosulfide (NaHS) at 0 (control), 10, 25, 50, 100, 200, and $400 \mu \mathrm{M}$ for $12 \mathrm{~h}, \mathrm{~A} 549$ cell viability was tested via a 3-(4, 5-dimethylthiazol-2-yl)-2, 5-diphenyltetrazolium bromide (MTT) assay. (B) MTT assay. A549 cells were treated with 20, 40, 60, 80, 100, and $200 \mathrm{mM} \mathrm{H}_{2} \mathrm{O}_{2}$ for $12 \mathrm{~h}$ and then subjected to an MTT assay. (C) MTT assay. A549 cells treated with serum-free medium, $50 \mu \mathrm{M} \mathrm{H}_{2} \mathrm{~S}$, and $60 \mathrm{mM} \mathrm{H}_{2} \mathrm{O}_{2}$ were the control group, $\mathrm{H}_{2} \mathrm{~S}$ group, and $\mathrm{H}_{2} \mathrm{O}_{2}$ group, respectively. A549 cells pre-treated with $\mathrm{H}_{2} \mathrm{~S}(50 \mu \mathrm{M})$ for $2 \mathrm{~h}$ and then subjected to $\mathrm{H}_{2} \mathrm{O}_{2}(60 \mathrm{mM})$ for $10 \mathrm{~h}$ were the protection group $\left(\mathrm{H}_{2} \mathrm{~S}+\mathrm{H}_{2} \mathrm{O}_{2}\right)$. (D) Flow cytometric cell apoptosis assay. Histograms depict proportions of total apoptotic cells. (E) Cell colony formation and microscopic morphology (200×). (F) The protein expression of caspase 3 was measured using western blot analysis and the caspase 3 activity was measured using a caspase 3 assay kit. (G) The mRNA expression and protein expression of Bax and Bcl-2 were detected using quantitative real-time PCR (qRT-PCR) and western blot analysis. The experiments were repeated at least three times. The results are presented as the mean $\pm \mathrm{SD}$. ${ }^{*} p<0.05,{ }^{* *} p<0.01,{ }^{* * *} p<0.001$ vs. corresponding control group; \#\# $p<0.01 \mathrm{H}_{2} \mathrm{O}_{2}$ group vs. $\mathrm{H}_{2} \mathrm{~S}+\mathrm{H}_{2} \mathrm{O}_{2}$ group).

\subsection{Protection Effect of $\mathrm{H}_{2} \mathrm{~S}$ on Reactive Oxygen Species Injury}

Upon $\mathrm{H}_{2} \mathrm{O}_{2}$ treatment, a massive production of intracellular reactive oxygen species (ROS) was observed. However, ROS production could be suppressed by pre-treatment of $\mathrm{H}_{2} \mathrm{~S}$ (Figure 2A). Superoxide dismutase (SOD) and glutathione peroxidase (GSH-PX) are the main oxygen free radical scavengers [26]. Catalase (CAT) is involved in peroxide breakdown and malondialdehyde (MDA) is one of the final products of polyunsaturated acid peroxidation [27]. Therefore, we decided to test the activities of SOD, GSH-PX, and CAT, and the MDA production in A549 cells. Our data showed that SOD, GSH-PX, and CAT activities were decreased in the $\mathrm{H}_{2} \mathrm{O}_{2}$ group compared to the control group. However, these phenomena were completely reversed by $\mathrm{H}_{2} \mathrm{~S}$ pre-treatment (Figure 2B-D). As shown 
in Figure 2E, $\mathrm{H}_{2} \mathrm{O}_{2}$ obviously increased MDA production, while $\mathrm{H}_{2} \mathrm{~S}$ pre-treatment efficiently lowered the content of MDA. These findings suggested that $\mathrm{H}_{2} \mathrm{~S}$ could attenuate $\mathrm{H}_{2} \mathrm{O}_{2}$-induced oxidative stress in A549 cells.

A

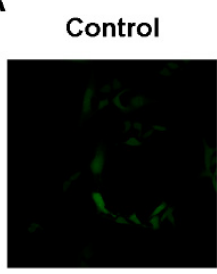

C

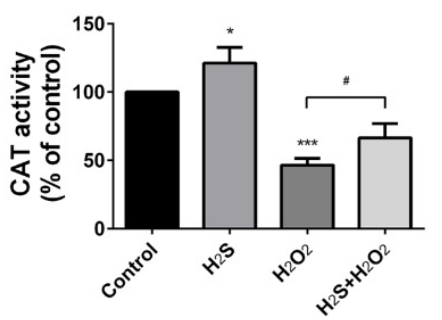

$\mathrm{H}_{2} \mathrm{~S}$

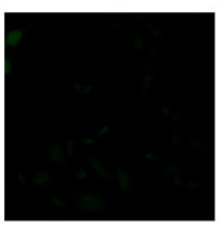

D

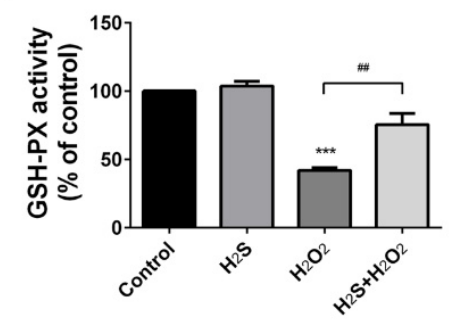

B

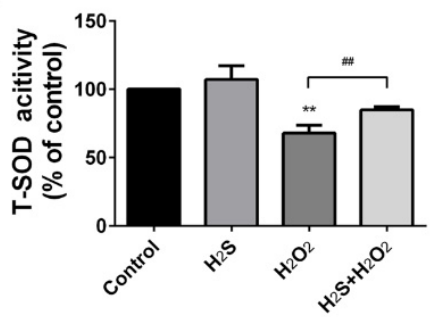

E

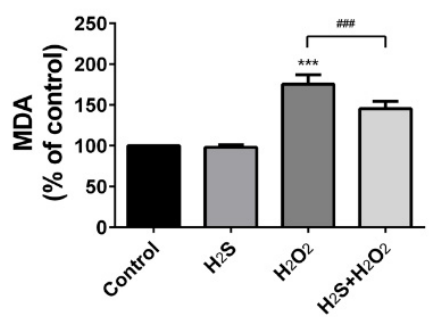

Figure 2. Hydrogen sulfide $\left(\mathrm{H}_{2} \mathrm{~S}\right)$ protected A549 cells against hydrogen peroxide $\left(\mathrm{H}_{2} \mathrm{O}_{2}\right)$-induced oxidative stress. (A) Intracellular superoxide anion production was detected with the dihydroethidium $2^{\prime}, 7^{\prime}$-dichloroflurescein-diacetate (DCFH-DA) and observed by a laser scanning confocal microscope $(400 \times)$. (B-D). The activities of superoxide dismutase (SOD), catalase (CAT), and glutathione peroxidase (GSH-PX) were measured. (E) The malondialdehyde (MDA) production was measured. The experiments were repeated at least three times. The results are presented as the mean \pm SD. $\left({ }^{*} p<0.05,{ }^{* *} p<0.01,{ }^{* * *} p<0.001\right.$ vs. corresponding control group; $\# p<0.05, \# \# p<0.01, \# \# \#<0.001$ $\mathrm{H}_{2} \mathrm{O}_{2}$ group vs. $\mathrm{H}_{2} \mathrm{~S}+\mathrm{H}_{2} \mathrm{O}_{2}$ group).

\section{3. $\mathrm{H}_{2} \mathrm{O}_{2}$ Suppressed Endogenous $\mathrm{H}_{2} \mathrm{~S}$ Production in A549 Cells}

Endogenous $\mathrm{H}_{2} \mathrm{~S}$ production was measured to further determine the effects of oxidative stress induced by $\mathrm{H}_{2} \mathrm{O}_{2}$. The results showed that the rates of $\mathrm{H}_{2} \mathrm{~S}$ production were significantly increased with $\mathrm{H}_{2} \mathrm{~S}$ treatment, while blocked by $\mathrm{H}_{2} \mathrm{O}_{2}$ treatment (Figure $3 \mathrm{~A}$ ). Inhibitory functions of $\mathrm{H}_{2} \mathrm{O}_{2}$ were confirmed by qRT-PCR analysis, which demonstrated that $\mathrm{H}_{2} \mathrm{O}_{2}$ suppressed $\mathrm{H}_{2} \mathrm{~S}$-producing enzymes CBS, CSE, and MPST expression (Figure 3B). Western blot analysis showed the same trend with the mRNA expression. $\mathrm{H}_{2} \mathrm{O}_{2}$ resulted in significant CBS, CSE, and MPST expression inhibition. However, pre-treatment of $\mathrm{H}_{2} \mathrm{~S}$ attenuated the reduction effect induced by $\mathrm{H}_{2} \mathrm{O}_{2}$ (Figure 3C,D). Therefore, we preliminarily determined that $\mathrm{H}_{2} \mathrm{O}_{2}$-induced oxidative injury was associated with endogenous $\mathrm{H}_{2} \mathrm{~S}$-producing enzymes. 
A

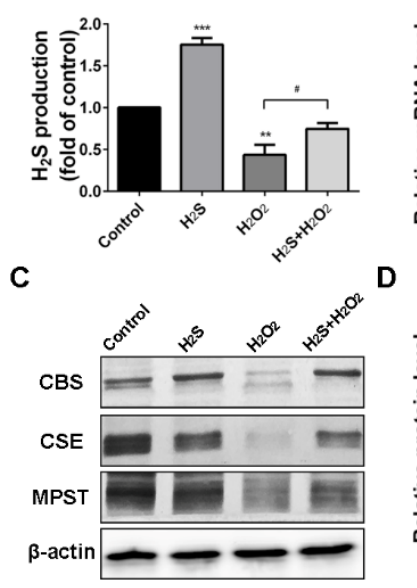

B
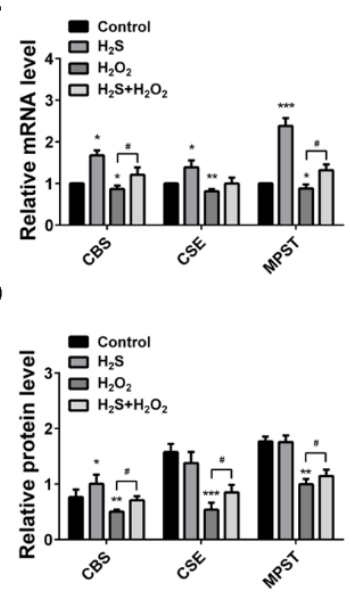

Figure 3. Hydrogen peroxide $\left(\mathrm{H}_{2} \mathrm{O}_{2}\right)$ suppressed endogenous hydrogen sulfide $\left(\mathrm{H}_{2} \mathrm{~S}\right)$ production and $\mathrm{H}_{2} \mathrm{~S}$-producing enzymes. (A) $\mathrm{H}_{2} \mathrm{~S}$ production tested using a methylene blue assay. (B) Quantitative real-time PCR (qRT-PCR) assay results for cystathionine-beta-synthase (CBS), cystathionine-gamma-lyase (CSE), and 3-mercapto-pyruvate sulfurtransferase (MPST) mRNA expression levels. (C) Western blot analysis of CBS, CSE, and MPST protein expression levels. (D) Quantitative analysis of CBS, CSE, and MPST band intensities. The experiments were repeated at least three times. The results are presented as the mean $\pm \mathrm{SD}$. $\left({ }^{*} p<0.05,{ }^{* *} p<0.01,{ }^{* * *} p<0.001 \mathrm{vs}\right.$. corresponding control group; \# $p<0.05$, \#\# $p<0.01 \mathrm{H}_{2} \mathrm{O}_{2}$ group vs. $\mathrm{H}_{2} \mathrm{~S}+\mathrm{H}_{2} \mathrm{O}_{2}$ group).

\subsection{Effect of $\mathrm{H}_{2} \mathrm{~S}$ on $\mathrm{H}_{2} \mathrm{O}_{2}$ Injury $\mathrm{A} 549$ Cells in Mitochondrial Membrane Potential $(\Delta \psi)$ and Energy Metabolism}

Mitochondrial function is highly susceptible to ROS injury, and the change in mitochondrial membrane potential $(\Delta \psi)$ is the sign of damage [28]. We investigated whether $\mathrm{H}_{2} \mathrm{~S}$ regulated $\Delta \psi$ change induced by $\mathrm{H}_{2} \mathrm{O}_{2}$. Mitochondria in the control group exhibited high $\Delta \psi$, which showed red fluorescence. However, mitochondria showed less intense red fluorescence, but more intense green fluorescence, with $\mathrm{H}_{2} \mathrm{O}_{2}$ exposure. $\mathrm{H}_{2} \mathrm{~S}$ pre-treatment could improve the red fluorescence intensity, which illustrated that $\mathrm{H}_{2} \mathrm{~S}$ might prevent the loss of $\Delta \psi$ (Figure $4 \mathrm{~A}$ ). $\mathrm{H}_{2} \mathrm{O}_{2}$-induced mitochondrial function injury directly resulted in the reduction of the ATP output, while $\mathrm{H}_{2} \mathrm{~S}$ could increase ATP production (Figure $4 \mathrm{~B}$ ). With $\mathrm{H}_{2} \mathrm{O}_{2}$ treatment, the enzymatic activity of lactate dehydrogenase (LDH) was decreased compared to the control group (Figure $4 \mathrm{C}$ ). Meanwhile, our results showed that $\mathrm{H}_{2} \mathrm{~S}$ accelerated the metabolic process, resulting in an increase of glucose consumption, lactic acid production, and pyruvate uptake (Figure $4 \mathrm{D}, \mathrm{F}$ ). These findings indicated that $\mathrm{H}_{2} \mathrm{O}_{2}$ decreased the mitochondrial membrane potential, as well as energy metabolism progress. 
A

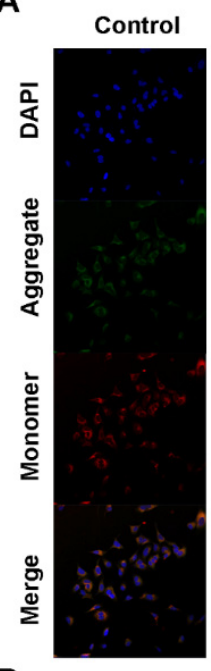

D

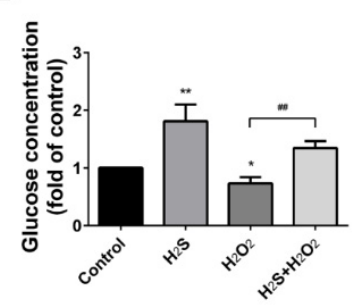

$\mathrm{H}_{2} \mathrm{~S}$

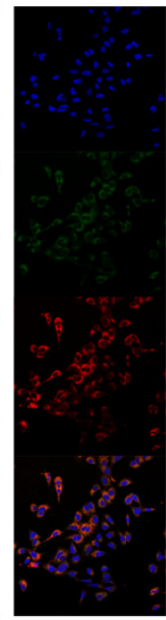

E

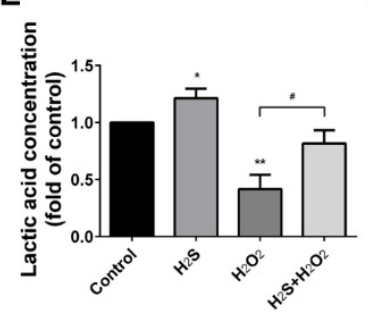

B

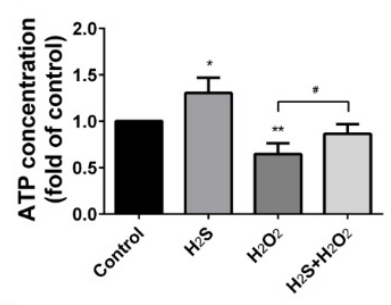

C

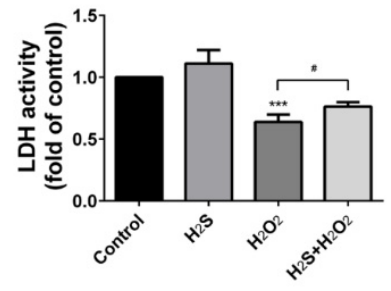

$\mathbf{F}$

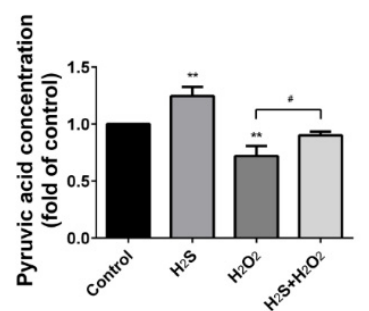

Figure 4. Hydrogen sulfide $\left(\mathrm{H}_{2} \mathrm{~S}\right)$ restores hydrogen peroxide $\left(\mathrm{H}_{2} \mathrm{O}_{2}\right)$-induced reduction of mitochondrial membrane potential $(\Delta \psi)$ and energy metabolism. (A) The $\Delta \psi$ was determined by lipophilic cationic probe JC-1 with a laser scanning confocal microscope (400×). Red signal indicated JC-1 in the mitochondrial matrix and green signal indicated JC-1 in cytosol. (B) ATP production ( $\mu \mathrm{mol} / \mathrm{g}$ protein) and (C) the enzymatic activity of lactate dehydrogenase (LDH) in A549 cells were measured. (D-F) Glucose consumption ( $\mu \mathrm{mol} / \mathrm{mg}$ protein), lactic acid production ( $\mathrm{mmol} / \mathrm{g}$ protein), and pyruvate uptake ( $\mu \mathrm{mol} / \mathrm{mg}$ protein) were measured with assay kits. The experiments were repeated at least three times. The results are presented as the mean $\pm \mathrm{SD} .\left({ }^{*} p<0.05,{ }^{* *} p<0.01\right.$ vs. corresponding control group; $\# p<0.05$, \#\# $p<0.01 \mathrm{H}_{2} \mathrm{O}_{2}$ group vs. $\mathrm{H}_{2} \mathrm{~S}+\mathrm{H}_{2} \mathrm{O}_{2}$ group).

\subsection{Effect of $\mathrm{H}_{2} \mathrm{~S}$ on ROS-Induced Intracellular $\left[\mathrm{Ca}^{2+}\right]$ and Endoplasmic Reticulum Stress}

The ER lumen is the main storage of $\left[\mathrm{Ca}^{2+}\right]$, and ER dysfunction promotes the calcium output [20]. We first detected intracellular $\left[\mathrm{Ca}^{2+}\right]$ with the Fluo-3, AM fluorescence probe, and the results showed that $\mathrm{H}_{2} \mathrm{~S}$ limited the $\left[\mathrm{Ca}^{2+}\right.$ ] overload under $\mathrm{H}_{2} \mathrm{O}_{2}$ stress (Figure 5A). GRP78 and CHOP, the two main ER stress markers, were measured by western blot analysis. As shown in Figure $5 \mathrm{~B}, \mathrm{H}_{2} \mathrm{O}_{2}$ injury contributed to the overexpression of GRP78 and CHOP, but $\mathrm{H}_{2} \mathrm{~S}$ pre-treatment blocked these increases. We further investigated the effect of $\mathrm{H}_{2} \mathrm{~S}$ on the ER stress pathway. $\mathrm{H}_{2} \mathrm{O}_{2}$ stimulated the phosphorylation expression of IRE1 and eIF2 $\alpha$, and then up-regulated ATF4 and ATF6. However, $\mathrm{H}_{2} \mathrm{~S}$ significantly decreased the level of ATF6, but had a slight effect on p-IRE1, p-eIF2 $\alpha$, and ATF4. Therefore, we preliminarily determined that $\mathrm{H}_{2} \mathrm{O}_{2}$ caused calcium overload via ER stress. 
A

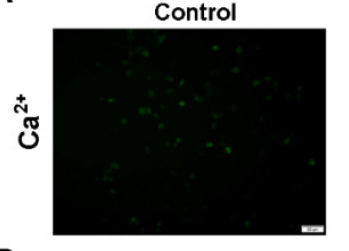

B

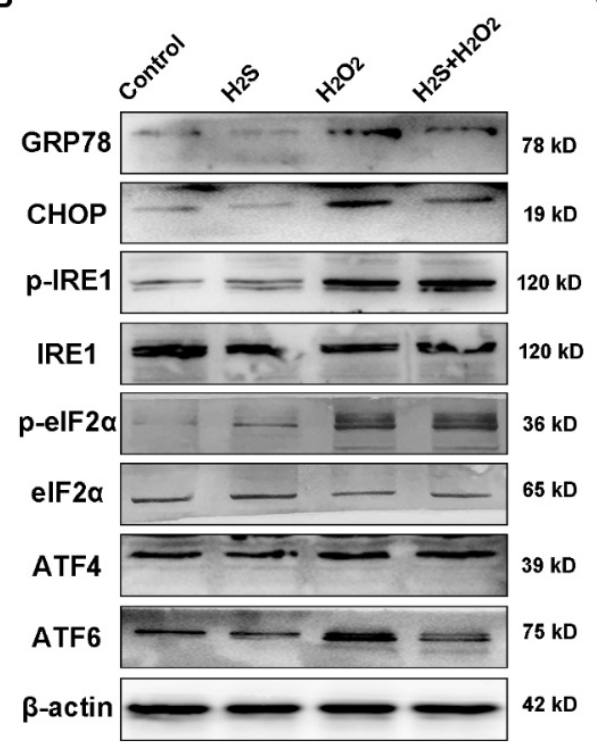

$\mathrm{H}_{2} \mathrm{~S}$

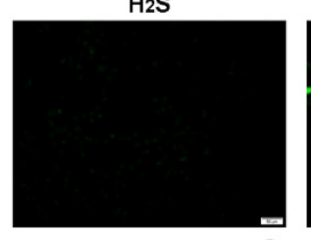

C
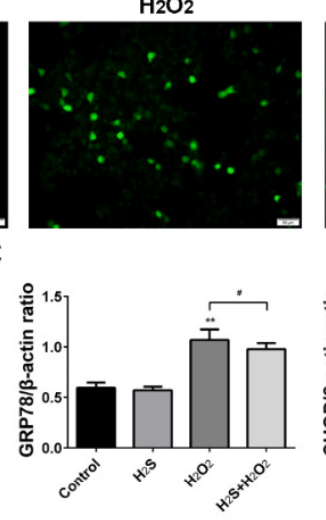
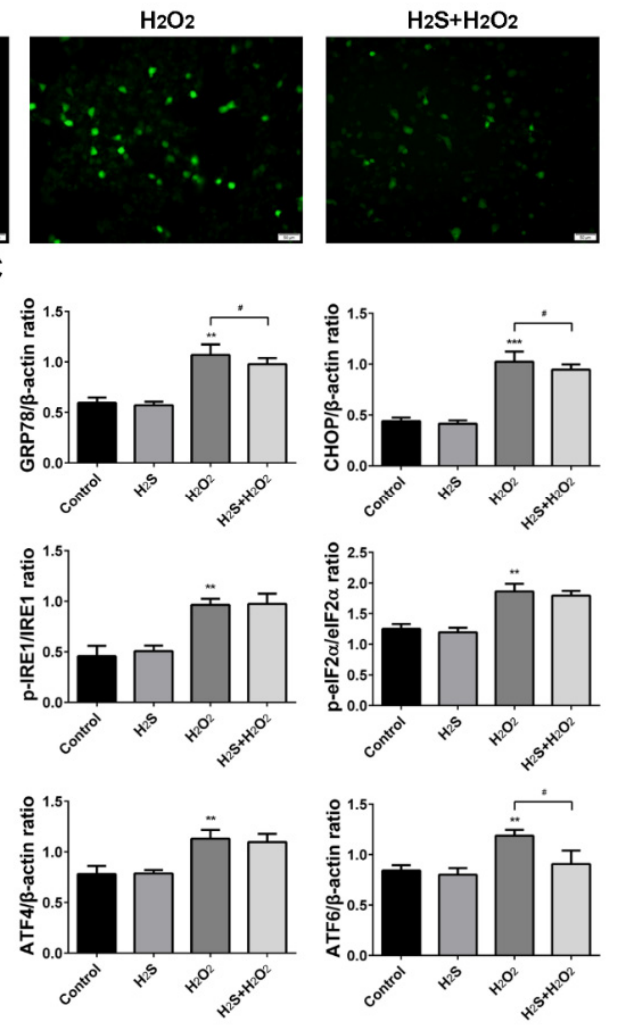

Figure 5. Hydrogen sulfide $\left(\mathrm{H}_{2} \mathrm{~S}\right)$ attenuates $\left[\mathrm{Ca}^{2+}\right]$ and endoplasmic reticulum (ER) stress induced by reactive oxygen species (ROS). (A) The calcium ion levels were detected with fluorescence probe Fluo-3, AM by a fluorescence microscope (200×). (B) Western blot analysis of GRP78, CHOP, phospho-IRE1, phospho-eIF2 $\alpha$, ATF4, and ATF6 upon different treatment. (C) Bar graphs show quantification of the protein levels. The experiments were repeated at least three times. The results are presented as the mean $\pm \mathrm{SD}$. ${ }^{*} p<0.05,{ }^{* *} p<0.01,{ }^{* * *} p<0.001$ vs. corresponding control group; $\# p<0.05 \mathrm{H}_{2} \mathrm{O}_{2}$ group vs. $\mathrm{H}_{2} \mathrm{~S}+\mathrm{H}_{2} \mathrm{O}_{2}$ group).

2.6. Effect of $\mathrm{H}_{2} \mathrm{~S}$ on the Mitogen-Activated Protein Kinase (MAPK) Signaling Pathway in $\mathrm{H}_{2} \mathrm{O}_{2}$-Treated A549 Cells

ROS play a crucial part in cells via regulation of the MAPK signaling pathway [29]. Herein, phosphorylated levels of p38, ERK, JNK, and AKT were examined via western blot analysis to investigate whether $\mathrm{H}_{2} \mathrm{O}_{2}$ was involved in MAPK pathway activation. The results showed that the phosphorylation of p38 and ERK was up-regulated and the phosphorylation of AKT was suppressed by $\mathrm{H}_{2} \mathrm{O}_{2}$ treatment, compared with that in the control group. However, $\mathrm{H}_{2} \mathrm{~S}$ pre-treatment decreased the p-p38 and p-ERK, but had little effect on p-JNK expression (Figure 6A,B). Therefore, the results suggested that $\mathrm{H}_{2} \mathrm{~S}$ mediated $\mathrm{H}_{2} \mathrm{O}_{2}$-induced MAPK activation in A549 cells. 
A

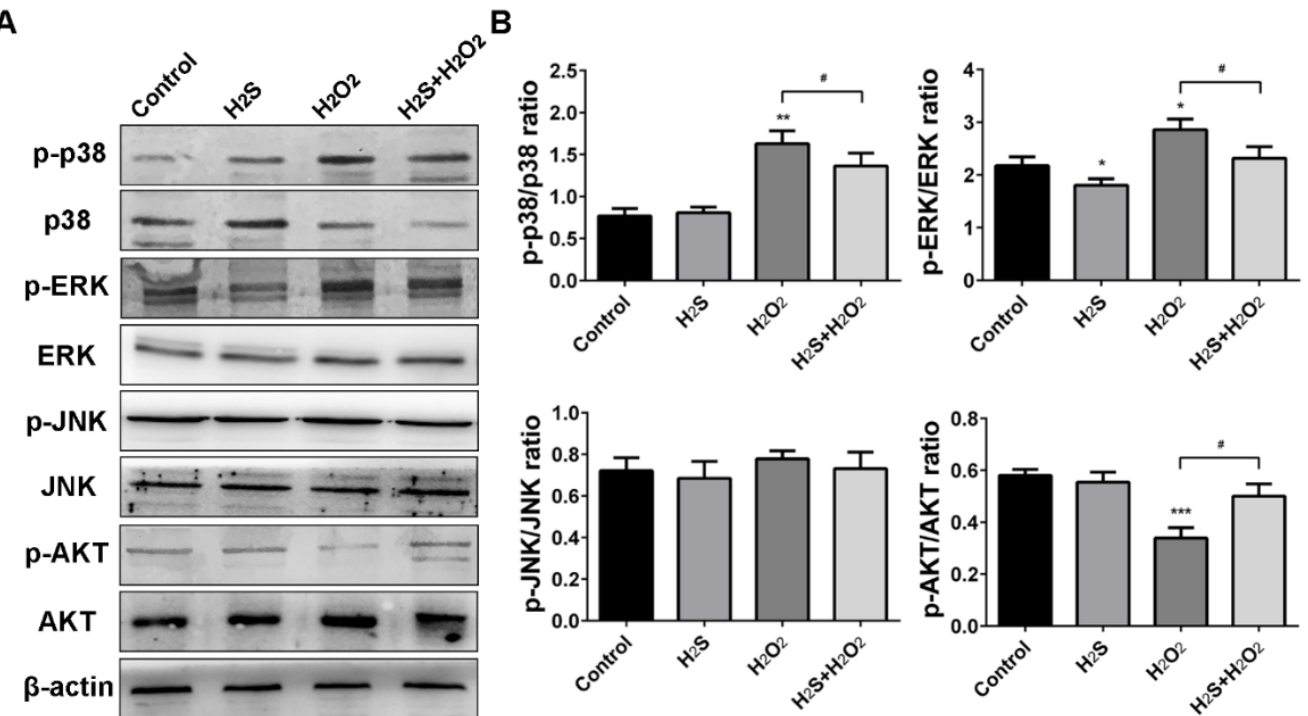

Figure 6. Hydrogen sulfide $\left(\mathrm{H}_{2} \mathrm{~S}\right)$ mediates hydrogen peroxide $\left(\mathrm{H}_{2} \mathrm{O}_{2}\right)$-induced mitogen-activated protein kinase (MAPK) activation in A549 cells. (A) The protein expressions of phospho-p38, phospho-ERK 1/2, phospho-JNK, and phospho-AKT were analyzed by western blot analysis. (B) Bar graphs shows quantification of the protein levels. The experiments were repeated at least three times. The results are presented as the mean $\pm \mathrm{SD}$. ${ }^{*} p<0.05,{ }^{* *} p<0.01,{ }^{* * *} p<0.001 \mathrm{vs}$. corresponding control group; $\# p<0.05 \mathrm{H}_{2} \mathrm{O}_{2}$ group vs. $\mathrm{H}_{2} \mathrm{~S}+\mathrm{H}_{2} \mathrm{O}_{2}$ group).

\section{Discussion}

Recently, a growing number of researches indicate that $\mathrm{H}_{2} \mathrm{~S}$ participates in the regulation of various physiological and pathological processes in the human body $[5,30,31]$. Our research found that 10-50 $\mu \mathrm{M}$ NaHS promoted cell proliferation. Therefore, the cyto-protective effect of $\mathrm{H}_{2} \mathrm{~S}$ could only be achieved at a low level of NaHS. The lung is susceptible to a hyperoxia environment, and excessive ROS production can damage the physiological functions of lung tissue, such as epithelial function, endothelial cells, and airway smooth muscle [32]. Therefore, preventing oxidative stress has become an important target for lung diseases. In this study, we investigated whether exogenous $\mathrm{H}_{2} \mathrm{~S}$ attenuated ROS-induced injury in human lung epithelial A549 cells. The results showed that $\mathrm{H}_{2} \mathrm{~S}$ protected $\mathrm{A} 549$ cells from $\mathrm{H}_{2} \mathrm{O}_{2}$-induced apoptosis, maintained the redox balance, and defended the oxidative stress. $\mathrm{H}_{2} \mathrm{~S}$ pre-treatment also preserved mitochondrial membrane potential, which was essential for ATP production and energy metabolism. Moreover, $\mathrm{H}_{2} \mathrm{~S}$ attenuated intracellular $\left[\mathrm{Ca}^{2+}\right]$ and ER stress induced by ROS.

$\mathrm{H}_{2} \mathrm{O}_{2}$ is widely used to model the oxidative stress of mammalian cells. The cell morphology, survival rate, and expression of apoptosis-associated proteins were detected to ensure that the oxidative injury model was successfully established for the subsequent experiments. The results showed that the A549 cell survival rate was $53.72 \pm 5.31 \%$ with stimulation of $60 \mathrm{mM} \mathrm{H}_{2} \mathrm{O}_{2}$, while the cell activity was increased by $17.75 \pm 4.69 \%$ for the $\mathrm{H}_{2} \mathrm{O}_{2}$ group with $50 \mu \mathrm{M} \mathrm{H}_{2} \mathrm{~S}$ pre-treatment. Moreover, lactate dehydrogenase, which is located in the cytoplasm of normal cells, but is released into the cell culture medium when cells are injured, is a sensitive marker of cell damage. $\mathrm{H}_{2} \mathrm{O}_{2}$ significantly increased LDH release (Figure S1), which demonstrated that the model was successfully constricted.

High levels of ROS could lead to an imbalance of the cellular redox state and oxidative stress, as well as induce cell apoptosis [33]. Therefore, we chose to measure intracellular reactive oxygen species, glutathione, superoxide dismutase, and malondialdehyde as the biomarker evaluation of oxidative damage. The results showed that $\mathrm{H}_{2} \mathrm{~S}$ could reverse the decrease of SOD, GSH-PX, and CAT and increase MDA induced by $\mathrm{H}_{2} \mathrm{O}_{2}$. In contrast, $\mathrm{H}_{2} \mathrm{O}_{2}$ suppressed the endogenous $\mathrm{H}_{2} \mathrm{~S}$ production and $\mathrm{H}_{2} \mathrm{~S}$-producing enzymes $\mathrm{CBS}, \mathrm{CSE}$, and MPST, to further enhance oxidative stress. Recent studies 
have demonstrated that cell apoptosis induced by ROS could activate the MAPK pathway [34]. ERK, JNK, and p38 are three of the main components in the MAPK family [35]. Our results indicate that $\mathrm{H}_{2} \mathrm{O}_{2}$ treatment triggered the phosphorylation of ERK and p38. However, pre-treatment with $\mathrm{H}_{2} \mathrm{~S}$ significantly altered $\mathrm{H}_{2} \mathrm{O}_{2}$-induced p-ERK and p-p38, but slightly altered p-JNK. Meanwhile, $\mathrm{H}_{2} \mathrm{~S}$ activated the phosphorylation of AKT to promote cell proliferation when A549 cells became injured. These results provide evidence for the critical roles of $\mathrm{H}_{2} \mathrm{~S}$ in ROS-induced apoptosis via the MAPK signaling pathway.

Mitochondria are the main sites of oxidative phosphorylation and ATP production [36]. $\mathrm{H}_{2} \mathrm{O}_{2}$ exposure causes the irreversible damage of mitochondria and loss of $\Delta \psi$ in cardiac fibroblasts [37]. Our previous study showed that a low concentration (less than $10 \mu \mathrm{M}$ ) of $\mathrm{H}_{2} \mathrm{~S}$ facilitated electron transport and participated in the regulation of mitochondrial respiration in a bovine heart in vitro [38]. Therefore, in this study, we aimed to investigate whether $\mathrm{H}_{2} \mathrm{~S}$ is involved in mitochondria stabilization in $\mathrm{H}_{2} \mathrm{O}_{2}$-induced lung injury. The results showed $\mathrm{H}_{2} \mathrm{O}_{2}$ decreased $\Delta \psi$ and inhibited the activities of metabolic enzymes, reducing energy production in A549 cells. A lack of energy due to oxidative damage further aggravated cell damage. However, $\mathrm{H}_{2} \mathrm{~S}$, which facilitated glucose utilization and increased ATP production, played a protective role in human lung epithelial cells. These findings indicate that $\mathrm{H}_{2} \mathrm{~S}$ neutralized the damaging effects of $\mathrm{H}_{2} \mathrm{O}_{2}$ in cell metabolism and mitochondria producing energy.

ER stress can activate apoptotic signals to remove the damaged cells. Under physiological conditions, GRP78 is bound to the three ER stress sensors inositol requiring enzyme 1 (IRE1), protein kinase RNA-like ER kinase (PERK), and activating transcription factor 6 (ATF6), to form a stable complex [39]. Under ER stress conditions, calcium dyshomeostasis and misfolded proteins accumulate in the ER. GRP78 is released from the sensors and triggers an unfold protein response (UPR) [40]. The stress sensors are activated, and in the meantime, up-regulate GRP78 and CHOP expression [41]. Our data indicate that $\mathrm{H}_{2} \mathrm{O}_{2}$ obviously increased the expression of GRP78 and CHOP. Following ER stress, three signaling pathways: the IRE1 pathway, the PERK/eIF2 $\alpha /$ ATF4 pathway, and the ATF6 pathway, were activated [42]. All these pathways are capable of altering the levels of Bcl-2 family members to elicit apoptosis [43]. Therefore, these three pathways were examined in response to $\mathrm{H}_{2} \mathrm{O}_{2}$ treatment. In the IRE1 pathway, $\mathrm{H}_{2} \mathrm{O}_{2}$ increased the phosphorylation of IRE1, but $\mathrm{H}_{2} \mathrm{~S}$ pre-treatment changed p-IRE1 expression slightly. In the second pathway, $\mathrm{H}_{2} \mathrm{O}_{2}$ activated p-ERK, resulting in a large increase of phospho-eIF $2 \alpha$ and ATF4. However, only a little change in p-eIF2 $\alpha$ and ATF 4 could be observed with $\mathrm{H}_{2} \mathrm{~S}$ pre-treatment. For the last pathway, the results showed that $\mathrm{H}_{2} \mathrm{~S}$ treatment significantly inhibited $\mathrm{H}_{2} \mathrm{O}_{2}$-induced AFT6 up-regulation. These findings indicated that the protective effect of $\mathrm{H}_{2} \mathrm{~S}$ against $\mathrm{H}_{2} \mathrm{O}_{2}$-induced injury was closely related to ER stress via the ATF6 pathway.

ER stress and oxidative stress together have an impact on many diseases, including diabetes, cardiovascular disease, and cancer [44-46]. Overwhelming ROS production disrupts the redox equilibrium in the ER lumen, leading to excessive ER stress and cell apoptosis [47-49]. Meanwhile, ER stress facilitates ROS overproduction and thus activates the $\mathrm{Ca}^{2+} / \mathrm{XO} / \mathrm{ROS} / \mathrm{mPTP}$ pathway [50]. Therefore, combination therapies that suppress both ROS and ER stress might be a potential therapeutic agent to protect lung injury. Our results show that pre-treatment with $\mathrm{H}_{2} \mathrm{~S}$ could counteract $\mathrm{ROS}$ and ER stress processes and might provide an effective way to regulate the tumor microenvironment.

\section{Materials and Methods}

\subsection{Cell Culture}

The human lung epithelial cell line A549 was obtained from the Cell Bank of the Chinese Academy of Sciences (Shanghai, China). Cells were cultured in RPMI-1640 medium (Solarbio Science \& Technology, Beijing, China) with $10 \%$ fetal bovine serum (FBS) at $37^{\circ} \mathrm{C}$ and $5 \% \mathrm{CO}_{2}$. NaHS and $\mathrm{H}_{2} \mathrm{O}_{2}$ were purchased from Sigma-Aldrich (St. Louis, MO, USA) and the solution was prepared immediately before use. A549 cells treated with serum-free medium, $50 \mu \mathrm{M} \mathrm{H} \mathrm{H}_{2} \mathrm{~S}$, and $60 \mathrm{mM} \mathrm{H}_{2} \mathrm{O}_{2}$ were the control 
group, $\mathrm{H}_{2} \mathrm{~S}$ group, and $\mathrm{H}_{2} \mathrm{O}_{2}$ group, respectively. A549 cells pre-treated with $\mathrm{H}_{2} \mathrm{~S}(50 \mu \mathrm{M})$ for $2 \mathrm{~h}$ and then subjected to $\mathrm{H}_{2} \mathrm{O}_{2}(60 \mathrm{mM})$ for $10 \mathrm{~h}$ were the protection group $\left(\mathrm{H}_{2} \mathrm{~S}+\mathrm{H}_{2} \mathrm{O}_{2}\right)$. A549 cells were rinsed with phosphate buffer saline (PBS) buffer three times after $\mathrm{H}_{2} \mathrm{~S}$ pretreatment, before subjecting the cells to $\mathrm{H}_{2} \mathrm{O}_{2}$ challenge. After $12 \mathrm{~h}$ of treatment, cells were then used for the subsequent experiments.

\subsection{Cell Viability and Colony Formation}

$1.0 \times 10^{4}$ cells were plated in 96-well plates to assess cell viabilities. Different concentrations of $\mathrm{NaHS}(0,10,25,50,100,200 \mu \mathrm{M})$ and $\mathrm{H}_{2} \mathrm{O}_{2}(0,20,40,60,80,100,200 \mathrm{mM})$ were added to the serum-free medium. After $12 \mathrm{~h}$ treatment, cells were assessed via an MTT assay and the optical density was measured at $490 \mathrm{~nm}$ by a multifunction microplate reader (Tecan Infinite, Mannedorf, Switzerland).

$3 \times 10^{2}$ A549 cells/well were seeded in 6-well plates for a colony formation assay. After two weeks, colonies were fixed in methanol, stained with $0.1 \%$ crystal violet, and photographed to count the number.

\subsection{Analysis of Cell Apoptosis}

The apoptosis assays were measured with a BBcellProbe ${ }^{\mathrm{TM}}$ Annexin V FITC/PI Apoptosis Detection Kit (BestBio, Shanghai, China). Briefly, A549 cells were collected in $400 \mu \mathrm{L}$ binding buffer and incubated with $5 \mu \mathrm{L}$ Annexin V and $10 \mu \mathrm{L}$ PI for $10 \mathrm{~min}$. A CytoFLEX flow cytometer (Beckman Coulter Life Sciences, Indianapolis, IN, USA) was used to measure apoptosis rates. Caspase 3 activity was detected by a caspase 3 activity assay kit (BestBio), according to the manufacturer's instructions. Briefly, after being lysed on ice for $30 \mathrm{~min}$, cellular proteins were incubated in reaction buffer with Ac-DEVD-pNA at $37^{\circ} \mathrm{C}$ for $4 \mathrm{~h}$. The $405 \mathrm{~nm}$ absorbance was measured via NanoDrop 2000 apparatus (Thermo Fisher Scientific, Waltham, MA, USA).

\subsection{Quantitative Real-Time PCR ( $q R T-P C R)$}

RNA was isolated using a Total RNA Purification Kit (BioTeke Corporation, Beijing, China), as per the manufacturer's instructions, and reverse transcribed into cDNA using a PrimeScript ${ }^{\mathrm{TM}}$ RT Reagent Kit with gDNA Eraser (TaKaRa, Bio, Kyoto, Japan). qRT-PCR was performed using SYBR Green PCR Mastermix (Solarbio Science \& Technology) and DNA amplification was performed using an Applied Biosystems ABI 7500 thermal cycler (Thermo Fisher Scientific). The results were calculated using the $2^{-\Delta \Delta \mathrm{Ct}}$ method. $\beta$-actin was the internal control. The primer sequences are listed in Table 1.

Table 1. Quantitative real-time PCR (qRT-PCR) primers used in the study.

\begin{tabular}{ccc}
\hline Gene & Forward $\left(\mathbf{5}^{\prime} \mathbf{-} \mathbf{3}^{\prime} \mathbf{)}\right.$ & Reverse $\mathbf{( 5}^{\prime} \mathbf{- 3}^{\prime} \mathbf{)}$ \\
\hline CBS & AATGGTGACGCTTGGGAA & TGAGGCGGATCTGTTTGA \\
CSE & AAGACGCCTCCTCACAAGGT & ATATTCAAAACCCGAGTGCTGG \\
MPST & GACCCCGCCTTCATCAAG & CATGTACCACTCCACCCA \\
Bax & TGGCAGCTGACATGTTTTCTGA & TCACCCAACCACCCTGGTCTT \\
Bcl- 2 & CAGTTGGGCAACAGAGAACCAT & AGCCCTTGTCCCCAATTTGGAA \\
$\beta$-actin & CTGGAACGGTGAAGGTGACA & AAGGGACTTCCTGTAACAATGCA \\
\hline
\end{tabular}

\subsection{Western Blot}

Cellular proteins were extracted in RIPA lysis buffer (BioTeke Corporation) on ice. An equal protein content of cell lysates was loaded onto sodium dodecyl sulfate-polyacrylamide gel electrophoresis, electrophoretically resolved, and then transferred onto polyvinylidene difluoride western blot membranes (Roche, Basel, Switzerland). The membranes were blocked for $3 \mathrm{~h}$ at $25{ }^{\circ} \mathrm{C}$ in $5 \%$ skim milk, and then incubated with specific primary and secondary antibodies. Immunoblots were detected using an ECL Western Blotting Substrate (Solarbio Science \& Technology) and visualized using a Tanon 5200 digital imaging system (Tanon Science \& Technology, Shanghai, China). Primary antibodies were caspase-3, cleaved-caspase-3, Bcl-2, Bax, GRP78, CHOP, IRE1, elF2 $\alpha$, ATF4, ATF6, 
p-38, p-p38, ERK, p-ERK, JNK, p-JNK, AKT and p-AKT (Wanleibio, Shenyang, China), $\beta$-actin, MPST, p-IRE1 (Bioss, Beijing, China), CBS, CSE (Omnimabs, Alhambra, CA, USA), and p-elF2 $\alpha$ (Abbkine, Wuhan, China). Secondary antibodies (goat anti-rabbit IgG/HRP antibody, goat anti-mouse IgG/HRP antibody) were purchased from Bioss. Western blotting quantification results were evaluated with Image J software.

\subsection{Measurement of $\mathrm{H}_{2} \mathrm{~S}$ in Cell Culture Supernatants}

$\mathrm{H}_{2} \mathrm{~S}$ production was tested using a methylene blue assay as per the manufacturer's instructions (Solarbio Science \& Technology). Briefly, the test is based on the reaction between $\mathrm{H}_{2} \mathrm{~S}$ and zinc acetate that forms zinc sulfide, which is then dissolved in N, N-dimethyl-p-phenylenediamine sulfate. Upon ammonium ferric sulfate addition, methylene blue forms were then quantified from the absorbance read using a UV-VIS spectrophotometer (UV-2700, Shimadzu, Kyoto, Japan).

\subsection{Measurement of $\left[\mathrm{Ca}^{2+}\right]$}

$\left[\mathrm{Ca}^{2+}\right]$ measurement was performed according to the manufacturer's instructions (Solarbio Science \& Technology). Briefly, A549 cells were incubated in hanks balanced salt solution (1\% FBS) with Fluo-3, $\mathrm{AM}$ at $37^{\circ} \mathrm{C}$ for $40 \mathrm{~min}$. Then, cells were washed with HEPES buffer saline three times and examined using IX73 fluorescence microscopy (Olympus, Kyoto, Japan).

\subsection{Measurement of Mitochondrial Membrane Potential $(\Delta \psi)$}

Mitochondrial membrane potential was measured with a mitochondria-specific cationic dye JC-1 (BestBio), according to the manufacturer's instructions. Briefly, A549 cells were incubated in dye buffer with $5 \mu \mathrm{L} \mathrm{JC}-1$ for $15 \mathrm{~min}$ at $37^{\circ} \mathrm{C}$ and observed using an LSM710 laser scanning confocal microscope (Carl Zeiss, Oberkochen, Germany).

\subsection{Reactive Oxygen Species (ROS), Malondialdehyde (MDA), Superoxide Dismutase (SOD), Glutathione (GSH), and Catalase-Peroxidase (CAT) Assays}

ROS was measured with $2^{\prime}, 7^{\prime}$-dichloroflurescein-diacetate (DCFH-DA, BestBio) and observed using an LSM710 laser scanning confocal microscope (Carl Zeiss). MDA content (Wanleibio), SOD activity, GSH concentration, and CAT activity (Solarbio Science \& Technology) were measured following the manufacturer's instructions.

\subsection{Metabolic Assays}

ATP production was detected using an ATP Bioluminescent Assay Kit (Nanjing Jiancheng Bioengineering Institute, Nanjing, China), according to the manufacturer's instructions. Glucose consumption assay, lactic acid production, pyruvate, and lactate dehydrogenase (LDH) were performed with a Glucose Measurement Assay Kit (Rongsheng Biotech, Shanghai, China), Lactic Acid Assay Kit (Nanjing Jiancheng Bioengineering Institute), Pyruvate Assay Kit (Nanjing Jiancheng Bioengineering Institute), and LDH Assay Kit (Wanleibio), respectively, according to the manufacturer's instructions.

\subsection{Statistical Analysis}

All results were expressed as means \pm standard deviation (SD) from at least three independent experiments. Data between-group differences were evaluated by two-tailed $t$-tests. SPSS 16.0 (IBM Corporation, Chicago, IL, USA) and GraphPad Prism 6.0 (GraphPad Software, La Jolla, CA, USA) software were used to perform all statistical analyses. Only results with $p$-value $<0.05$ were considered statistically significant. 


\section{Conclusions}

In summary, our results demonstrated that $\mathrm{H}_{2} \mathrm{~S}$ reduced ROS production and markedly inhibited apoptosis induced by $\mathrm{H}_{2} \mathrm{O}_{2}$, as well as maintained the structural and functional integrity of the mitochondria in A549 cells. Moreover, $\mathrm{H}_{2} \mathrm{~S}$ attenuated $\left[\mathrm{Ca}^{2+}\right]$ overload and ER stress induced by $\mathrm{H}_{2} \mathrm{O}_{2}$. These findings might provide an effective way to counteract ROS and ER stress processes in $\mathrm{H}_{2} \mathrm{O}_{2}$-induced lung injury.

Supplementary Materials: Supplementary materials can be found at http://www.mdpi.com/1422-0067/20/16/ 3975/s1.

Author Contributions: Conceptualization and writing—original draft preparation, M.W.; investigation, M.W., X.C., and C.L.; software and formal analysis, X.C.; project administration and funding acquisition, Z.L.

Funding: This work was supported by the National Natural Science Foundation of China (No. 31670797).

Acknowledgments: We thanked the EasyEdition for editing and proofreading this manuscript.

Conflicts of Interest: The authors declare no conflicts of interest.

\section{Abbreviations}

$\begin{array}{ll}\mathrm{H}_{2} \mathrm{~S} & \text { hydrogen sulfide } \\ \mathrm{H}_{2} \mathrm{O}_{2} & \text { hydrogen peroxide } \\ \text { CBS } & \text { cystathionine-beta-synthase } \\ \text { CSE } & \text { cystathionine-gamma-lyase } \\ \text { MPST } & \text { 3-mercapto-pyruvate sulfurtransferase } \\ \text { ER } & \text { endoplasmic reticulum } \\ \text { MAPK } & \text { mitogen-activated protein kinase } \\ \text { ROS } & \text { reactive oxygen species } \\ \text { NaHS } & \text { sodium hydrosulfide } \\ \text { IC } 50 & \text { half maximal inhibitory concentration } \\ \text { MTT } & \text { 3-(4, 5-dimethylthiazol-2-yl)-2, 5-diphenyltetrazolium bromide } \\ \text { DCFH-DA } & \text { 2',7'-dichloroflurescein-diacetate } \\ \text { SOD } & \text { superoxide dismutase } \\ \text { GSH-PX } & \text { glutathione peroxidase } \\ \text { CAT } & \text { catalase } \\ \text { MDA } & \text { malondialdehyde } \\ \triangle \psi & \text { mitochondrial membrane potential } \\ \text { ATP } & \text { adenosine triphosphate } \\ \text { LDH } & \text { lactate dehydrogenase } \\ \text { IRE1 } & \text { inositol requiring enzyme 1 } \\ \text { PERK } & \text { protein kinase RNA-like ER kinase } \\ \text { ATF6 } & \text { activating transcription factor 6 } \\ \text { UPR } & \text { unfold protein response } \\ \text { FBS } & \text { fetal bovine serum } \\ \text { qRT-PCR } & \text { quantitative real-time PCR } \\ \text { PBS } & \text { phosphate buffer saline } \\ \text { NSAIDS } & \text { nonsteroidal anti-inflammatory drugs } \\ & \end{array}$

\section{References}

1. Di Masi, A.; Ascenzi, P. $\mathrm{H}_{2} \mathrm{~S}$ : a “double face” molecule in health and disease. Biofactors 2013, 39, $186-196$. [CrossRef] [PubMed]

2. Yang, B.; Bai, Y.; Yin, C.; Qian, H.; Xing, G.; Wang, S.; Li, F.; Bian, J.; Aschner, M.; Lu, R. Activation of autophagic flux and the Nrf2/ARE signaling pathway by hydrogen sulfide protects against acrylonitrile-induced neurotoxicity in primary rat astrocytes. Arch. Toxicol. 2018, 92, 2093-2108. [CrossRef]

3. Wang, R. Hydrogen sulfide: the third gasotransmitter in biology and medicine. Antioxid. Redox Signal. 2010, 12, 1061-1064. [CrossRef] [PubMed] 
4. Hellmich, M.R.; Szabo, C. Hydrogen Sulfide and Cancer. Handb. Exp. Pharmacol. 2015, 230, $233-241$. [PubMed]

5. Szabo, C.; Coletta, C.; Chao, C.; Modis, K.; Szczesny, B.; Papapetropoulos, A.; Hellmich, M.R. Tumor-derived hydrogen sulfide, produced by cystathionine-beta-synthase, stimulates bioenergetics, cell proliferation, and angiogenesis in colon cancer. Proc. Natl. Acad. Sci. USA 2013, 110, 12474-12479. [CrossRef] [PubMed]

6. Ivanciuc, T.; Sbrana, E.; Ansar, M.; Bazhanov, N.; Szabo, C.; Casola, A.; Garofalo, R.P. Hydrogen Sulfide Is an Antiviral and Antiinflammatory Endogenous Gasotransmitter in the Airways. Role in Respiratory Syncytial Virus Infection. Am. J. Respir. Cell Mol. Biol. 2016, 55, 684-696. [CrossRef] [PubMed]

7. Szabo, C. Hydrogen sulphide and its therapeutic potential. Nat. Rev. Drug Discov. 2007, 6, 917-935. [CrossRef] [PubMed]

8. Kimura, H. Hydrogen sulfide: its production, release and functions. Amino Acids 2011, 41, 113-121. [CrossRef] [PubMed]

9. Gargallo, C.J.; Lanas, A. Is NSAIDs-related gastrointestinal damage preventable? J. Dig. Dis. 2013, 14, 55-61. [CrossRef]

10. Gemici, B.; Elsheikh, W.; Feitosa, K.B.; Costa, S.K.; Muscara, M.N.; Wallace, J.L. H ${ }_{2}$ S-releasing drugs: anti-inflammatory, cytoprotective and chemopreventative potential. Nitric Oxide 2015, 46, 25-31. [CrossRef]

11. Hsia, C.C.; Hyde, D.M.; Weibel, E.R. Lung Structure and the Intrinsic Challenges of Gas Exchange. Compr. Physiol. 2016, 6, 827-895. [PubMed]

12. Groneberg-Kloft, B.; Kraus, T.; Mark, A.; Wagner, U.; Fischer, A. Analysing the causes of chronic cough: relation to diesel exhaust, ozone, nitrogen oxides, sulphur oxides and other environmental factors. J. Occup. Med. Toxicol. 2006, 1, 6. [CrossRef] [PubMed]

13. Kallet, R.H.; Matthay, M.A. Hyperoxic acute lung injury. Respir. Care 2013, 58, 123-141. [CrossRef] [PubMed]

14. Escaffre, O.; Saito, T.B.; Juelich, T.L.; Ikegami, T.; Smith, J.K.; Perez, D.D.; Atkins, C.; Levine, C.B.; Huante, M.B.; Nusbaum, R.J.; et al. Contribution of Human Lung Parenchyma and Leukocyte Influx to Oxidative Stress and Immune System-Mediated Pathology following Nipah Virus Infection. J. Virol. 2017, 91, e00275-17. [CrossRef] [PubMed]

15. Varga, Z.V.; Ferdinandy, P.; Liaudet, L.; Pacher, P. Drug-induced mitochondrial dysfunction and cardiotoxicity. Am. J. Physiol. Heart Circ. Physiol. 2015, 309, H1453-H1467. [CrossRef]

16. Fudulu, D.; Angelini, G. Oxidative Stress after Surgery on the Immature Heart. Oxid. Med. Cell Longev. 2016, 2016, 1971452. [CrossRef]

17. Liao, P.H.; Hsu, H.H.; Chen, T.S.; Chen, M.C.; Day, C.H.; Tu, C.C.; Lin, Y.M.; Tsai, F.J.; Kuo, W.W.; Huang, C.Y. Phosphorylation of cofilin-1 by ERK confers HDAC inhibitor resistance in hepatocellular carcinoma cells via decreased ROS-mediated mitochondria injury. Oncogene 2017, 36, 1978-1990. [CrossRef]

18. Zorov, D.B.; Juhaszova, M.; Sollott, S.J. Mitochondrial reactive oxygen species (ROS) and ROS-induced ROS release. Physiol. Rev. 2014, 94, 909-950. [CrossRef]

19. Wang, Y.; Wang, K.; Jin, Y.; Sheng, X. Endoplasmic reticulum proteostasis control and gastric cancer. Cancer Lett. 2019, 449, 263-271. [CrossRef]

20. Marciniak, S.J. Endoplasmic reticulum stress in lung disease. Eur. Respir. Rev. 2017, 26, 170018. [CrossRef]

21. Jeong, J.S.; Kim, S.R.; Cho, S.H.; Lee, Y.C. Endoplasmic Reticulum Stress and Allergic Diseases. Curr. Allergy Asthma Rep. 2017, 17, 82. [CrossRef] [PubMed]

22. Santos, L.E.; Ferreira, S.T. Crosstalk between endoplasmic reticulum stress and brain inflammation in Alzheimer's disease. Neuropharmacology 2018, 136, 350-360. [CrossRef] [PubMed]

23. Mozzini, C.; Cominacini, L.; Garbin, U.; Fratta Pasini, A.M. Endoplasmic Reticulum Stress, NRF2 Signalling and Cardiovascular Diseases in a Nutshell. Curr. Atheroscler. Rep. 2017, 19, 33. [CrossRef] [PubMed]

24. Yilmaz, E. Endoplasmic Reticulum Stress and Obesity. Adv. Exp. Med. Biol. 2017, 960, 261-276. [PubMed]

25. Wei, J.; Rahman, S.; Ayaub, E.A.; Dickhout, J.G.; Ask, K. Protein misfolding and endoplasmic reticulum stress in chronic lung disease. Chest 2013, 143, 1098-1105. [CrossRef]

26. Herken, H.; Uz, E.; Ozyurt, H.; Sogut, S.; Virit, O.; Akyol, O. Evidence that the activities of erythrocyte free radical scavenging enzymes and the products of lipid peroxidation are increased in different forms of schizophrenia. Mol. Psychiatry 2001, 6, 66-73. [CrossRef]

27. Fujimura, N.; Sumita, S.; Aimono, M.; Masuda, Y.; Shichinohe, Y.; Narimatsu, E.; Namiki, A. Effect of free radical scavengers on diaphragmatic contractility in septic peritonitis. Am. J. Respir. Crit. Care Med. 2000, 162, 2159-2165. [CrossRef] 
28. Sun, C.K.; Zhang, X.Y.; Sheard, P.W.; Mabuchi, A.; Wheatley, A.M. Change in mitochondrial membrane potential is the key mechanism in early warm hepatic ischemia-reperfusion injury. Microvasc. Res. 2005, 70, 102-110. [CrossRef]

29. Zhang, G.; He, J.; Ye, X.; Zhu, J.; Hu, X.; Shen, M.; Ma, Y.; Mao, Z.; Song, H.; Chen, F. beta-Thujaplicin induces autophagic cell death, apoptosis, and cell cycle arrest through ROS-mediated Akt and p38/ERK MAPK signaling in human hepatocellular carcinoma. Cell Death Dis. 2019, 10, 255. [CrossRef]

30. Wang, R. Physiological implications of hydrogen sulfide: a whiff exploration that blossomed. Physiol. Rev. 2012, 92, 791-896. [CrossRef]

31. Wallace, J.L.; Blackler, R.W.; Chan, M.V.; Da Silva, G.J.; Elsheikh, W.; Flannigan, K.L.; Gamaniek, I.; Manko, A.; Wang, L.; Motta, J.P.; et al. Anti-inflammatory and cytoprotective actions of hydrogen sulfide: translation to therapeutics. Antioxid Redox Signal. 2015, 22, 398-410. [CrossRef] [PubMed]

32. Nadeem, A.; Siddiqui, N.; Alharbi, N.O.; Alharbi, M.M. Airway and systemic oxidant-antioxidant dysregulation in asthma: a possible scenario of oxidants spill over from lung into blood. Pulm. Pharmacol. Ther. 2014, 29, 31-40. [CrossRef] [PubMed]

33. Circu, M.L.; Aw, T.Y. Reactive oxygen species, cellular redox systems, and apoptosis. Free Radic Biol. Med. 2010, 48, 749-762. [CrossRef] [PubMed]

34. Hao, W.; Yuan, X.; Yu, L.; Gao, C.; Sun, X.; Wang, D.; Zheng, Q. Licochalcone A-induced human gastric cancer BGC-823 cells apoptosis by regulating ROS-mediated MAPKs and PI3K/AKT signaling pathways. Sci. Rep. 2015, 5, 10336. [CrossRef] [PubMed]

35. Johnson, G.L.; Lapadat, R. Mitogen-activated protein kinase pathways mediated by ERK, JNK, and p38 protein kinases. Science 2002, 298, 1911-1912. [CrossRef]

36. Addabbo, F.; Montagnani, M.; Goligorsky, M.S. Mitochondria and reactive oxygen species. Hypertension 2009, 53, 885-892. [CrossRef]

37. Feng, A.; Ling, C.; Xin-Duo, L.; Bing, W.; San-Wu, W.; Yu, Z.; Yu-Lan, H.; You-En, Z. Hydrogen Sulfide Protects Human Cardiac Fibroblasts Against $\mathrm{H}_{2} \mathrm{O}_{2}$-induced Injury Through Regulating Autophagy-Related Proteins. Cell Transplant. 2018, 27, 1222-1234. [CrossRef]

38. Su, Y.B.; Cheng, Y.K.; Wang, D.D.; Zhang, F.R.; Su, Y.W.; Li, Z.Q. Effects of hydrogen sulfide $\left(\mathrm{H}_{2} \mathrm{~S}\right)$ on respiration control of state 3/4 in mitochondria from bovine heart. Afr. J. Biotechnol. 2012, 11, 4876-4883.

39. Kozutsumi, Y.; Segal, M.; Normington, K.; Gething, M.J.; Sambrook, J. The presence of malfolded proteins in the endoplasmic reticulum signals the induction of glucose-regulated proteins. Nature 1988, 332, $462-464$. [CrossRef]

40. Tajiri, S.; Oyadomari, S.; Yano, S.; Morioka, M.; Gotoh, T.; Hamada, J.I.; Ushio, Y.; Mori, M. Ischemia-induced neuronal cell death is mediated by the endoplasmic reticulum stress pathway involving CHOP. Cell Death Differ. 2004, 11, 403-415. [CrossRef]

41. Sano, R.; Reed, J.C. ER stress-induced cell death mechanisms. Biochim. Biophys. Acta 2013, 1833, 3460-3470. [CrossRef] [PubMed]

42. Hammadi, M.; Oulidi, A.; Gackiere, F.; Katsogiannou, M.; Slomianny, C.; Roudbaraki, M.; Dewailly, E.; Delcourt, P.; Lepage, G.; Lotteau, S.; et al. Modulation of ER stress and apoptosis by endoplasmic reticulum calcium leak via translocon during unfolded protein response: Involvement of GRP78. FASEB J. 2013, 27, 1600-1609. [CrossRef] [PubMed]

43. Oyadomari, S.; Mori, M. Roles of CHOP/GADD153 in endoplasmic reticulum stress. Cell Death Differ. 2004, 11, 381-389. [CrossRef] [PubMed]

44. Liu, Z.W.; Zhu, H.T.; Chen, K.L.; Dong, X.; Wei, J.; Qiu, C.; Xue, J.H. Protein kinase RNA-like endoplasmic reticulum kinase (PERK) signaling pathway plays a major role in reactive oxygen species (ROS)-mediated endoplasmic reticulum stress-induced apoptosis in diabetic cardiomyopathy. Cardiovasc. Diabetol. 2013, 12, 158. [CrossRef] [PubMed]

45. Ochoa, C.D.; Wu, R.F.; Terada, L.S. ROS signaling and ER stress in cardiovascular disease. Mol. Aspects Med. 2018, 63, 18-29. [CrossRef] [PubMed]

46. Wang, Z.; Yin, F.; Xu, J.; Zhang, T.; Wang, G.; Mao, M.; Wang, Z.; Sun, W.; Han, J.; Yang, M.; et al. CYT997(Lexibulin) induces apoptosis and autophagy through the activation of mutually reinforced ER stress and ROS in osteosarcoma. J. Exp. Clin. Cancer Res. 2019, 38, 44. [CrossRef] [PubMed] 
47. Verfaillie, T.; Rubio, N.; Garg, A.D.; Bultynck, G.; Rizzuto, R.; Decuypere, J.P.; Piette, J.; Linehan, C.; Gupta, S.; Samali, A.; et al. PERK is required at the ER-mitochondrial contact sites to convey apoptosis after ROS-based ER stress. Cell Death Differ. 2012, 19, 1880-1891. [CrossRef]

48. Chen, W.; Li, P.; Liu, Y.; Yang, Y.; Ye, X.; Zhang, F.; Huang, H. Isoalantolactone induces apoptosis through ROS-mediated ER stress and inhibition of STAT3 in prostate cancer cells. J. Exp. Clin. Cancer Res. 2018, 37, 309. [CrossRef]

49. Hayashi, T.; Saito, A.; Okuno, S.; Ferrand-Drake, M.; Dodd, R.L.; Chan, P.H. Damage to the endoplasmic reticulum and activation of apoptotic machinery by oxidative stress in ischemic neurons. J. Cereb. Blood Flow Metab. 2005, 25, 41-53. [CrossRef]

50. Zhu, P.; Hu, S.; Jin, Q.; Li, D.; Tian, F.; Toan, S.; Li, Y.; Zhou, H.; Chen, Y. Ripk3 promotes ER stress-induced necroptosis in cardiac IR injury: A mechanism involving calcium overload/XO/ROS/mPTP pathway. Redox Biol. 2018, 16, 157-168. [CrossRef]

(C) 2019 by the authors. Licensee MDPI, Basel, Switzerland. This article is an open access article distributed under the terms and conditions of the Creative Commons Attribution (CC BY) license (http://creativecommons.org/licenses/by/4.0/). 